\title{
An Effective Method of Acquiring Efficient-Critical Reading Skills For Students: Reading Group Activity
}

\section{Meltem Koçak}

Turkish Language and Literature Teacher, Haci Ömer Tarman Anatolian High School

Today, one of the most important indicators of a country's development level is the reading rate of that country. Studies show that the reading rate is quite low in our country. This situation has many reasons such as social, psychological and traditional ones. One of the most important reasons is the lack of reading education.

Reading is a rich activity combining vision, recognition, comprehension, inquiry, comprehension, speaking, writing and production. Completing the process with all these actions makes the reader active reader. The effective reading of individuals who have acquired basic reading skills depends on the enrichment of activities with comprehension, speaking, writing and production activities during reading process. Effective one is a reader who likes reading, spends time with reading, questions what he reads, makes written and oral text, and can use his readings for himself and his community and makes inferences from the readings. Effective reading makes the reading activity of the person pleasant. The individual discovers something new like an exploration at every stage after basic reading through seeing, recognizing and understanding. These discoveries trigger creativity that includes imagination as well as past experiences. The easiest and shortest way of reaching the pleasure of producing something is experienced with effective reading.

Giving importance to reading education in schools, teaching effective reading methods to students and providing them with feasible and sustainable reading projects will make a significant contribution to educating a generation who read, write, speak and produce in our country.

In this study, the reading group activity, which is applied with a group of secondary school (high school) students, was introduced and the practicing results of the activity were evaluated.

The target group of the students is 9 th, 10th and 11th grade students. The target audience was firstly informed about effective-critical reading and reading group activity was introduced. The application based on voluntary participation was started with a reading group consisting of six people. In the following times, participation increased and fifteen reading groups, each consisting of six and seven individuals, were formed in the three months. During the reading process, groups were guided and process evaluations were made. In order for the groups participating in the event to share their reading experiences with other students, it was provided to make presentations in the Z-library and arrange a 
book interview. Moreover, the reading activities of the groups within the scope of the Libraries Week were presented to the visitors through posters and presentations. Presentations were recorded with photographs and videos. It has been observed that reading group activity, which became widespread in school in a short time, increased the interest of students in reading and library. Students have learned the effective-critical reading of the role-tasks offered by the group readings, and have gained other skills such as orienting their readings, making reading preferences, and distinguishing qualified works. Reading group activity is an effective reading method which can be applied in all schools under the guidance of Turkish and literature teachers and supports active-critical reading, reading habits and culture.

Keywords: Effective-critical reading, reading group, reading culture, Z-library

\section{INTRODUCTION}

Today one of the most important indicators of the level of development of a country is the reading level of that country. Turkey Reading Culture Map (2011) data shows that the attitudes and actions towards reading culture in our country is quite poor. By considering these data Aras stated that the average number of books read is insufficient and low when the data are evaluated, whereas the rate of watching television is high, generally the textbooks are purchased, the majority of the people do not know about the services of public libraries, they do not benefit from these libraries, there is no general reading culture and reading habits and it is seen that there is not a writer or publishing house which is followed (Aras and Gökşen 2017).

Özdemir (2017) states that a good reader should acquire critical reading skills which improve the mindset and responsibility. This will lead him or her to become an intellectual and concludes that critical reading is a crucial tool for the development and progress of a society (Özdemir, pp. 11-28, 2017).

Reading is analyzing and vocalizing a text by looking at the signs and letters in it. Secondary meaning of it is understanding the hidden messages and meanings of a given text (TDK Turkish Language Dictionary). These definitions reveal two stages of reading skill: First, the basic reading skill gained by speaking the language formed in the written form of the language and understanding the clear message; the second is the critical reading skill, which allows to understand and analyze the implicit messages of the text. The realization of the second stage is directly related to the nature of the reading culture of the individual. The direction of the reading, the works, 
writers, publishers and periodicals and the attitudes and behaviors towards them constitute the reading culture. (Sever and Sedat 2013)

If a reader likes reading, has reading habits, guides the reading choices, follows state of art readings as well as the classical pieces, has writer and poet preferences, questions what is read, shares the experience, and discusses ideas with others, has conclusions from the text and apply these conclusions to the daily life, we can say that reading culture is acquired. Such a profile for a reader is the target of all countries. The age of information and technology that we are in needs to change information very quickly and needs individuals to keep up with this change. Our age is waiting for the qualified person to reach the information quickly, to grasp it quickly and to carry the information forward. At this point, access to information and critical-creative reading are gaining importance.

Giving importance to reading education in schools, to teach effective reading methods to students, to provide them with libraries and to offer them feasible, sustainable reading projects, will make a significant contribution to educating a generation who read, write, speak and produce in our country.

\section{Problem Statement:}

In our country where the reading culture is weak, it is seen that young people at the high school age have less interest in reading activities.

Our young people do not know what to read, why and how to read them. Except for the textbooks, they know where to use them. This problem reduces their interest in reading.

\section{Methodology}


We need effective reading techniques to direct young people to read. We need to provide young people with reading techniques that will enable them to be active-critical and creative, direct their readings, shape them, use them in their lives and have a direct effect on their reading cultures. In his study on the subject Kaya has made some observations on how to support the reading culture of the school by listing examples of effective reading activities. Some of the activities listed by Kaya are communicative voice reading, dual reading, silent reading, book presentation, literature club and drama. In this order, Kaya, who mentioned how each method will be applied and its achievements, states that the related activities emphasize the importance of the book as well as gaining the love and desire of reading. (Kaya and Meral nd Turkish Language Journal, pp. 608$622, \mathrm{TDK})$

For the reading activity, which is the subject of this study, the activity of the reading groups in the lecture notes of the Literature Club and Ayşe Yüksel Durukan's* lecture notes, which is based on the book of Harvey Daniels (Daniels, 1994), is taken as the basis.

The activity is called "Reading Group Activity". Kaya and Durukan's models were developed first and used in the creation and implementation of the event.

\section{Reading Group Activity}

The Reading Group Activity is a conversation activity that unites students, who read the same book in the same time interval with different roles and perspectives, to share their opinions and discuss their ideas about the book.

It is an activity that requires group work, cooperation, supports students' communication, multiplies their sharing, improves creative-critical aspects and provides quick feedback from what they read. In addition to the social skills such as role-playing, responsibility sharing, and ownership of group presence, the students discover their own abilities, develop their writing, speaking and listening skills, and acquire the attitudes and behaviors required by the discussion environments.

\footnotetext{
*Librarian at school
} 
Students attending the event are encouraged to gain persistent attitudes and behaviors related to reading culture. In addition, adaptation to the social life is also supported with this activity.

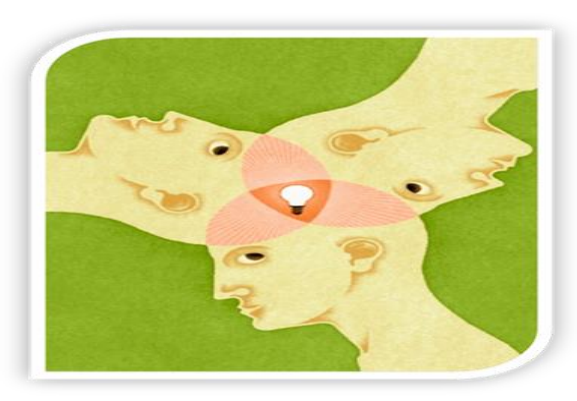

Figure 1

\section{The role-tasks selected for the Reading Group activity are:}

Supervisor, Illuminator, Linker, Painter, Word Magician, Reporter

\section{Supervisor:}

$\mathrm{He} / \mathrm{she}$ prepares questions about comprehension, directs his / her friends to questioning and provides coordination in the group.

While executing the discussion, the supervisor draws attention to the questions about understanding the text in different angles such as; subject, theme, structure, heroes, plot, space and time elements of the event; the characteristics of the author, the way the subject is handled, the language and narrative features of the text, the way of expression of the narrator, the important events and heroes that change the flow in the plot, the mentality of the period of the text, the mentality of the main heroes, the relation between historical reality and the theme of the present reality, the value of the society, the literary traditions to which the author is attached, the general and special aims that push the writer to write this text, the aspects of the important 
characters of the text connected to historical reality and the aspects that do not conform to reality.

\section{Illuminator:}

The illuminator reads important, surprising, thought-provoking, innovative, extraordinary, humorous, interesting passages that he/she finds in the book and reads them aloud to his friends and initiates verbal sharing to interpret the text with these passages. The illuminator brings them together with the materials that support their friends' readings.

\section{Linker:}

The linker considers the mentality or theme in the work he reads or the various meanings to the extent that the work permits, in the ways that the work permits, examines the other periods of the literature, the branches of science or art, the tradition, making references to such fields, and building bridges between the discourses, persons, events and situations.

\section{Word Magician:}

The word magician takes notes of words and phrases that are interesting to him (repetitions, images, symbols, metaphors, idioms and proverbs). He questions these in various ways such as the reasons for being used in the text, the relationship with the mindset and the theme, the meaning values that they are loaded in the work piece, the values of individual and social life other than the work fiction.

\section{Reporter:}

The reporter notes important events, characters, actions affecting the fiction of the book he reads with the $5 \mathrm{~W} 1 \mathrm{H}$ rule (what, where, when, how, why, who) and shares them with his friends, makes the news of the book.

\section{Painter:}

The artist draws the scenes which, he or she finds interesting in the book, with creation. In these works, symbolic pictures can be made as well as pictures reflecting events and characters. The plot of the novel can be given in the form of comics. The book summary can be illustrated. 


\section{FINDINGS}

In the first stage, 15 reading groups, each consisting of 6 or 7 members, were established for the reading group activity. In the reading groups of 7 persons, the $7^{\text {th }}$ person has taken the role of characterizing. 7. Some of the reading groups have also prepared group posters for Z-library event presentations. Figure 2 shows the poster design that all groups use in common. Figure 3 shows the examples of the special posters prepared by the groups according to the books

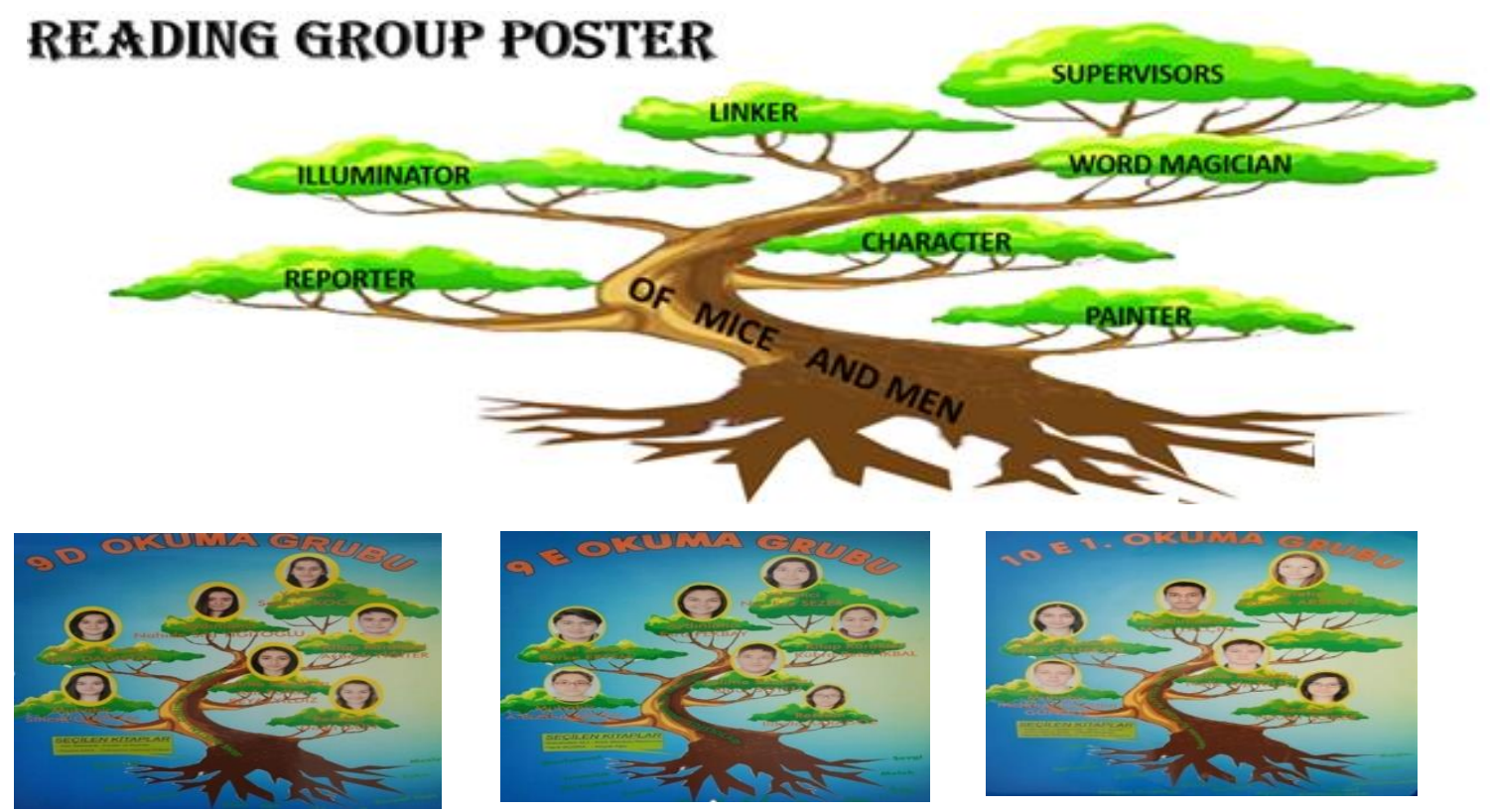

Figure 3: Examples of the Group Posters from Reading Group Activity

Findings related to role tasks are listed below separately.

\section{Supervisors}

1. They learned to install responsibility.

2. They led the group.

3. They directed the reading process. 
4. They prepared evaluation questions to understand the form and content of the text.

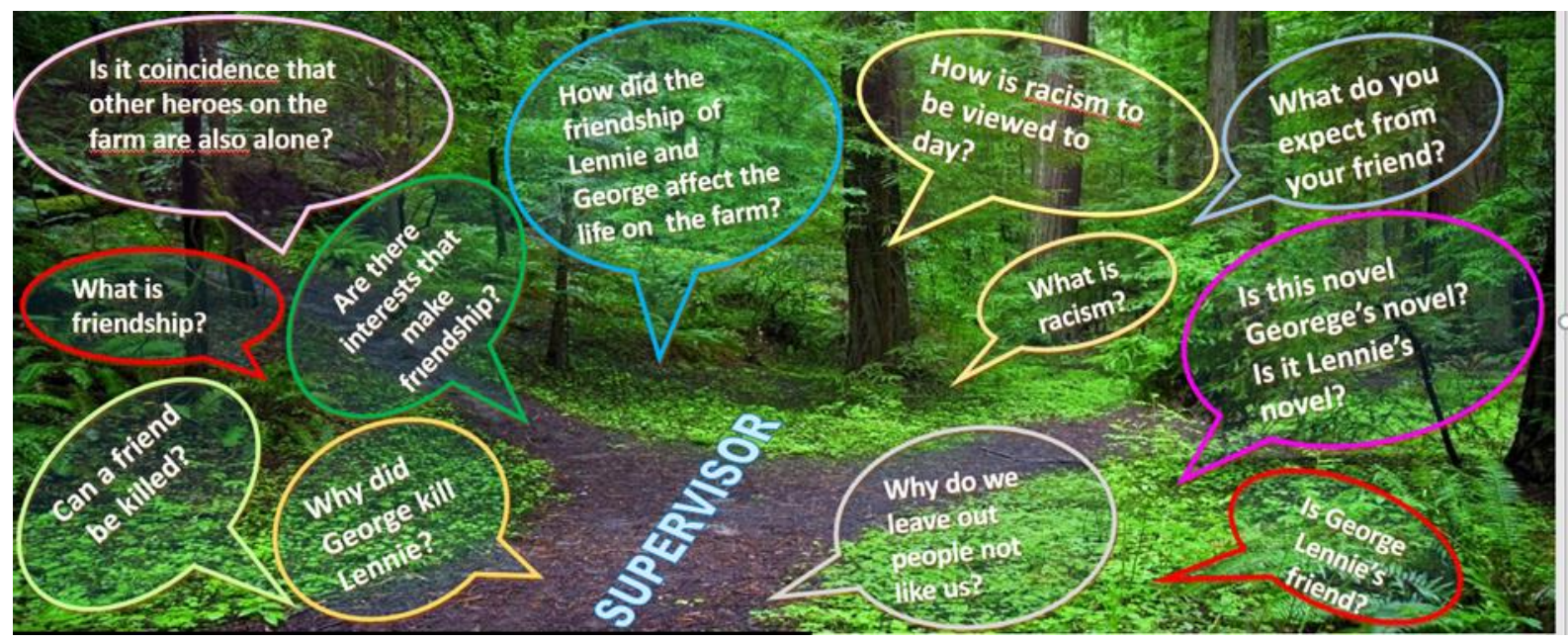

Figure 4: Of Mice and Man Supervisor Questions

\section{Linkers}

They made creative readings by associating the mindset, theme or various meanings in the work with other works, period, science or art, tradition, genre fields to the extent that the work allowed.

Example:

The link by considering type-character analysis between Crime and Punishment and the Hunchback of Notre Dame novels.

The linker, who read both of the two novels, presented the fact that the character described below by Raskolnikov and Quasimodo share same character, therefore, these two novels share similar meanings in terms of type-character analysis. This was accepted by the other members and the group prepared and presented a drama show that led Raskolnikow and Quasimado to the same stage. A tirade of Raskolnikow is given below which leads the student to link relation between two novels.

"Raskolnikow: ...Quite a number of them (ordinary people) by some freak of nature such as is not impossible even among cows...like to fancy that they are progressives, "destroyers" and 
propagators of the "new word" and all this quite sincerely. Any man who has one (a conscience) must suffer if he is conscious of error".

\section{Word Magicians:}

1. Distinguishing the words, phrases, idioms and proverbs and folk expressions that are frequently repeated, repetitive, interesting, having symbolic and imaginative meanings, and questioning their relations with the theme, genre or period, enriched the meaning of the text.

2. Students' skills to use language effectively are improved.

3. Our word wizards created concept maps based on the keywords of the book.

Example:

The evaluation of "Of Mice and Men" novel by using concept map, which is created by word magician

\begin{tabular}{|c|c|c|}
\hline $\begin{array}{l}\text { Name of the } \\
\text { concept }\end{array}$ & $\begin{array}{l}\text { Characters } \\
\text { representing } \\
\text { the concept }\end{array}$ & Interpretation of the concept \\
\hline Dream & $\begin{array}{l}\text { Lennie, } \\
\text { George, } \\
\text { Candy, } \\
\text { Curley's } \\
\text { Wife } \\
\end{array}$ & $\begin{array}{l}\text { There are four heroes in this book that are processed through } \\
\text { imagination. However, all four have different dreams. }\end{array}$ \\
\hline Loneliness & $\begin{array}{l}\text { George, } \\
\text { Candy, } \\
\text { Curley's } \\
\text { Wife, Crooks } \\
\text { and Slim } \\
\end{array}$ & $\begin{array}{l}\text { It can be said that all the heroes of the novel are combined } \\
\text { under the theme of loneliness. However, these are the heroes } \\
\text { whose loneliness are told by giving sections from their lives. }\end{array}$ \\
\hline Exclusion & $\begin{array}{l}\text { Crooks and } \\
\text { Lennie }\end{array}$ & $\begin{array}{l}\text { Since Crooks is black, he cannot live on the farm under the } \\
\text { same conditions as other workers. The other workers on the } \\
\text { farm casted out him. Lennie is weak due to his inadequate } \\
\text { mental balance. For this reason, it has an adaptation problem. } \\
\text { The farmers don't want to admit him. }\end{array}$ \\
\hline
\end{tabular}




\begin{tabular}{|c|c|c|}
\hline Friendship & $\begin{array}{c}\text { Lennie and } \\
\text { George }\end{array}$ & $\begin{array}{c}\text { We see Lennie and George here. These two main characters } \\
\text { represent the friendship with the extreme commitment they } \\
\text { show to each other from the beginning of the book. Other } \\
\text { heroes envy the friendship of Lennie and George. }\end{array}$ \\
\hline Responsibility & George & $\begin{array}{c}\text { George has been responsible for Lennie who was not very } \\
\text { good at his mental balance since the beginning of the novel, } \\
\text { and this situation continued until the end of the novel. The } \\
\text { fact that George killed Lennie at the end of the novel is the } \\
\text { result of his responsibility. }\end{array}$ \\
\hline Disappoinment & $\begin{array}{c}\text { Gurley's wife } \\
\text { and reader }\end{array}$ & $\begin{array}{c}\text { Curley's wife had a bad marriage. She is subjected to } \\
\text { violence from her husband Curley. She starts a number of } \\
\text { questh frustration. George eventually ends his own } \\
\text { dreams by killing Lenni. }\end{array}$ \\
\hline
\end{tabular}

\section{CONCEPT MAP}
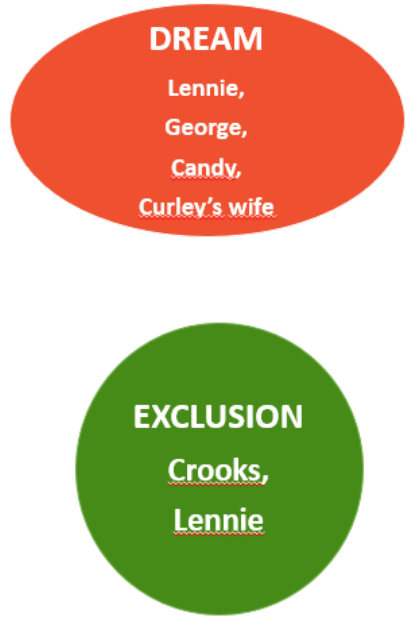
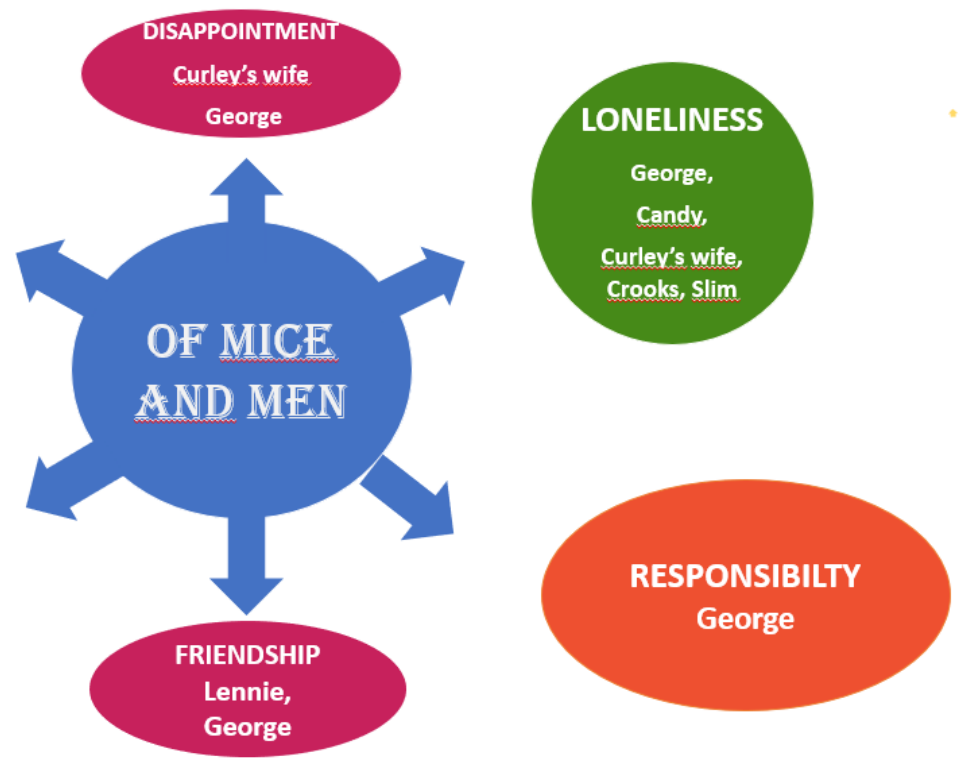

Figure 5: Of Mice and Man Concept Map

\section{Reporters;}

1. They have learned preparing the news text.

2. They translated the book introductions into news texts. 


\section{Painters:}

1. They drew the scenes creativity that they find impressive and valuable with their own creativity.

2. In these works, they made symbolic pictures as well as descriptive pictures.

3. They explained the connection of the drawings with the book.

\section{CONCLUSION}

It has been observed that reading group activity, which became widespread in school in a short time, increased the interest of students in reading and library. Students have learned how to read effectively-critically and creatively with the role-tasks presented by group readings, and acquired the ability to make reading preferences and to distinguish qualified works. In addition, creative writing skills and listening and speaking skills have also improved.

\section{SUGGESTIONS}

Novel is a kind of text based on reflecting human reality. Other role tasks can also be used in order to evaluate the human life. Reading group activity can be enriched with the inclusion of other role-tasks such as philosophers, sociologists, dancers, musicians and actors. 


\section{REFERENCES}

1. Aras, G. (2017) Edebiyat ve kültür: bireysel ve toplumsal gelişmede okuma ve kütüphane alışkanlığı üzerine. Hitit Üniversitesi, Sosyal Bilimler Enstitüsü Dergisi, 2, 963.

2. Daniels, H. (1994) Literature Circles: Voice and Choice in the Student-Centered Classroom. Stenhouse Publishers

3. Kaya, M. (2014) Okuma kültürü ve çocuk edebiyatı. Türk Dili, CVII, 608-622.

4. Özdemir, E. (2017) Eleştirel okuma, pp. 11-28. Ankara, Kök Yayıncılık.

5. Sever, S. (2015) Çocuk edebiyatı ve okuma kültürü. İzmir, Tudem Yayınları. 